\title{
М.А.КОвАЛЬчУК *
}

\section{УКРАЇНСЬКІ ВІЙСЬКОВІ ЧАСТИНИ В ОДЕСІ ЗА ЦЕНТРАЛЬНОЇ РАДИ: ФОРМУВАННЯ, ОРГАНІЗАЦІЯ, БОЙОВИЙ ШЛЯХ}

\begin{abstract}
На підставі широкого кола джерел, у толу числі й уперше введених у науковий обіг, досліджується історія українських національних військових фборлувань в Одесі в 1917 - на початку 1918 рр. Докладно відтворено основні етапи організацї̈ та бойової діяльності гайдамацьких частин, що були головною збройною силою уряду УНР на півдні України. Розглянуто широке коло питань, пов'язаних з впливол українських діячів і російських воєначальників на створення підрозділів національного війська в Одесі. Визначено основні засади організації військових фбормувань, зроблено висновок про їх відповідність вимогал часу.
\end{abstract}

Ключові слова: Центральна Рада, революиія, Українська Народна Республіка, Армія УНР, украйнський військовий рух.

Історія українських військових формувань в Одесі в 1917-1918 рр. досі не отримала належного висвітлення в науковій літературі. Наявні у працях з історії збройних сил Центральної Ради відомості про формування та бойовий шлях одеських гайдамаків надмірно узагальнені ${ }^{1}$ або ж страждають на значні фрактологічні неточності й перекручення ${ }^{2}$. Навіть присвячена висвітленню цієї теми праця одеських дослідників, яка побачила світ 2010 р., змогла заповнити лише частину «білих плям» ${ }^{3}$. Імовірно, такий стан вивчення теми пояснюється тим, що переважна більшість документів Одеського військового округу періоду 1917-1918 рр. зберігається нині у фондах Російського державного військовоісторичного архіву в Москві. Досі не введені в науковий обіг, ці матеріали містять надзвичайно цінні відомості про організаційну структуру й командний склад українських військових формувань на півдні України в 1917 - на початку 1918 рр. Свого часу нам удалося опрацювати ці документи (незважаючи на незадовільний фізичний стан деяких із них). Доповнивши отримані відомості знахідками з інших архівів нашої країни, а також Росії, залучивши спогади сучасників і матеріали преси, ми спробували висвітлити історію українських частин в Одесі впродовж 1917-1918 рр.

Зародження українського військового руху на теренах Причорномор'я навесні 1917 р. нерозривно пов'язане з ім'ям І.Луценка. Лікар за фрахом, він майже

* Ковальчук Михайло Анатолійович - кандидат історичних наук, старший науковий співробітник Інституту украӥнської археографбї та джерелознавства ілені М.С.Грушевського НАН України, відділ джерел із новітньої історї̈ України

E-mail: mitchel.kov.hist@gmail.com

1 Стефбанів 3. Українські збройні сили. - Ч.І: Доба Центральної Ради й Гетьманату. - [Б.м.], 1947. - 120 с.; Голубко В. Армія Української Народної Республіки 1917-1918: Утворення та боротьба за державу. - Л., 1997. - 288 с.; Солдатенко В.Ф., Хало Л.Г. Військовий чинник у боротьбі за політичну владу в Україні в 1917-1918 рр. - К., 2002. - 398 с.

2 Тинченко Я. Перша українсько-більшовицька війна (грудень 1917 - березень 1918). - К.; Л., 1996. - 372 с.; Його ж. Українські збройні сили: Березень 1917 р. - листопад 1918 р. (організація, чисельність, бойові дії). - К., 2009. - 480 с.

3 Див.: Вінцковський Т., Джумига Є., Мисечко А. Українські мілітарні формування в Одесі в добу Центральної Ради (березень 1917 - квітень 1918 рр.). - Одеса, 2010. - 154 с. 
чверть століття жив і працював в Одесі, де став організатором «Просвіти» й лідером місцевих українців. За свідченням сучасника, після Лютневої революції «всю справу об’єднання українців в Одесі взяв до своїх рук лікар Луценко»" Один із молодших учасників національного руху згадував: «Цей сивий дідусь, дуже тихої поваги, був всюди. Ні одні сходини, ні одне засідання чи порада не відбулися без нього; і все він подавав ріжні резолюції, що їх ми, молоді, завжди 3 радістю підпирали» ${ }^{5}$. Палкий прихильник незалежності України, І.Луценко приділяв першорядну увагу створенню національних збройних сил.

На початку 1917 р. гарнізон Одеси налічував близько 100 тис. вояків ${ }^{6}$. Зокрема в місті дислокувалися 40-й, 45-й, 46-й, 48-й і 49-й запасні піхотні полки, 5-й гарматний запасний дивізіон, запасні кулеметні батальйони, 1-й авіапарк, авіаційна школа при заводі "Анатра", піхотне й гарматне юнкерські військові училища, школи прапорщиків, дружини державного ополчення. Крім того, на рейді Одеського порту стояли кораблі Чорноморського фрлоту. Місто було адміністративним центром військового округу, який охоплював Херсонщину, Катеринославщину, Таврію, Бессарабію й південну частину Поділля. Будучи тиловим районом Румунського фрронту, цей регіон мав стратегічне значення для російської армії.

Оскільки серед вояків одеської залоги було чимало українців, після Лютневої революції в багатьох підрозділах з'явилися національні осередки. Але відсутність свідомих діячів серед командного складу призвела до того, що керівництво українським військовим рухом здійснювали молодші офріцери - прапорщики П.Вербецький і П.Голобородько, підпоручик М.Шевченко. Упродовж квітня 1917 р. чисельність організованих вояків-українців досягла декількох тисяч. «Ця група була молода і своєю організацією, і віком членів, свідчив очевидець та учасник українського військового руху в Одесі прапорщик Г.Гришко. - Але кількістю вона була тоді найбільша, а характером праці й активністю найжвавіша; вона була найпередніша й, так би мовити, найбільш революційна» ${ }^{7}$.

Окрім українських військових гуртків, в Одесі за підтримки І.Луценка навесні 1917 р. виникла українська спортивна молодіжна організація «Січ», що приймала до своїх лав не зобов'язаних до служби в армії юнаків віком від 16 років. Наприкінці весни «Січ» налічувала близько сотні молодих людей, командиром яких став Т.Янів - ветеран легіону УСС, котрий опинився у «Великій Україні» як військовополонений ${ }^{8}$.

9 травня 1917 р. було створено Одеську українську військову раду, діяльність якої мала охоплювати Одеський військовий округ (ОВО), Румунський

\footnotetext{
${ }^{4}$ Государственный архив Российской Федерации (далі - ГАРФ). - Ф.5881. - Оп.1. - Д.583. Л.58.

5 Гришко Г. 1917 рік в Одесі (Спомини з часів визвольних змагань) // Розбудова нації. - 1928. Ч.9. - С.129.

${ }^{6}$ Великий Жовтень і громадянська війна на Україні: Енциклопедичний довідник. - К., 1987. C.386.

7 Гришко Г. 1917 рік в Одесі... - С.129.

8 Липа Ю. Одеська «Січ» // Українське козацтво. - 1972. - Ч.3 (21). - С.13-14; Український національно-визвольний рух: Березень - листопад 1917 року: Документи і матеріали. - К., 2003. - C.730.
} 
фрронт і Чорноморський фрлот. Головою організації обрали І.Луценка, його заступником став підпоручик М.Шевченко, секретарем - прапорщик П.Вербецький. Уже на першому своєму засіданні рада заслухала інформацію про створення в Киеві Українського полку ім. Б.Хмельницького. Обговоривши перешкоди, які чинило цьому формуванню російське командування, члени ради вирішили поки що не домагатися організації українських полків в Одесі, але клопотатися про українізацію вже наявних частин.

Однак ці вимоги не знайшли розуміння з боку головного начальника ОВО генерала М.Ебелова. Вірменин за національністю, він зайняв ворожу позицію щодо українського національного руху й, посилаючись на відсутність необхідних повноважень, відмовився розглядати можливість українізації військових частин. На початку червня 1917 р. відносини між командуванням округу та українською військовою радою загострилися до такої міри, що остання навіть ухвалила «припинити одправку маршових рот із Одеси до того часу, поки в Одесі не будуть зорганізовані українські військові частини 3 існуючих ${ }^{10}$. 13 червня рада створила організаційно-мобілізаційну комісію для формування українських частин у складі військ ОВО й Румунського фронту. I хоча комісія мала працювати в контакті зі штабом округу, було заявлено, що без її згоди «не повинні одправлятись на фронт ніякі маршові роти, ні окремі військові особи» ${ }^{11}$.

Апогеєм українського військового руху в Одесі стало велелюдне солдатське віче, котре відбулося 6 липня 1917 р. під стінами штабу округу. За повідомленнями преси, його учасниками були 12 тис. вояків-українців, до яких долучилися також молдавани ${ }^{12}$. На зборах лунали заклики приступити до українізації полків та створення молдавських військових підрозділів. Серед інших промовців перед зібранням виступили головний начальник ОВО генерал М.Ебелов та його начальник штабу генерал Н.Маркс, котрі намагалися відмовити учасників віча від їхніх намірів ${ }^{13}$. Під приводом того, що створення національних частин виходить поза компетенцію штабу округу, обидва ґенерали оголосили будь-які самочинні військові формування незаконними. Погодившись передати це питання на розгляд вищої військової влади, вояки-українці утрималися від організації національних частин явочним порядком. Усіляко намагаючись запобігти ескалації конфлікту, штаб округу почав відправляти українські маршові роти до складу українізованих частин Румунського фронту.

У розпал суперечок довкола питання про створення національного війська, Одесу відвідав ротмістр О.Сахно-Устимович. Уродженець Полтавщини, він був кадровим офіцером російської армії та справжнім романтиком козацької старовини. Будучи навесні 1917 р. ад’ютантом головного начальника Київського військового округу генерала М.Ходоровича, О.Сахно-Устимович став членом організаційного комітету зі створення 1-го Українського полку

\footnotetext{
9 Український національно-визвольний рух... - С.259-260. Див. також: Гришко Г. 1917 рік в Одесі... - С.133.

10 Український національно-визвольний рух... - С.344.

11 Там само. - С.356.

12 Совещание по украинскому вопросу // Одесские новости. - 1917. - 24 июня. - №10450. - С.3.

13 Украинцы и молдаване // Там же; Совещание по украинскому вопросу. - С.3.
} 
ім. Б.Хмельницького ${ }^{14}$. Невдовзі він відбув на Румунський фрронт, де взяв активну участь в українському національному русі. У червні 1917 р. О.СахнаУстимовича було обрано головою українського з їзду 4-ї армії ${ }^{15}$.

Ознайомившись з організаційними проектами військової ради, О.СахноУстимович зі згоди І.Луценка взявся за формування в Одесі українських частин ${ }^{16}$. Аби обійти штаб Одеського округу, він звернувся по дозвіл до командувача 4-ї армії генерала О.Рогози. Останній, як українець за національністю, погодився на створення в Одесі українського партизанського загону, який після завершення формування мав відбути до складу 4-ї армії. Командувач Румунського фрронту генерал Д.Щербачов не заперечував проти цього проекту. Готуючись розпочати наприкінці липня 1917 р. наступ, він прагнув отримати у своє розпорядження всі можливі військові сили.

У російській армії «партизанськими загонами» називалися мобільні підрозділи, що діяли у ворожому тилу або ж на фрлангах із метою знищення комунікацій, завдання противникові матеріальних втрат, здійснення розвідувальної діяльності. Зазвичай їх формували з добровольців і складалися вони з кінноти та легкої артилерії. Упродовж 1914-1917 рр. завдяки своїм діям стали відомими партизанські загони капітана Леонтьєва, поручика Л.Пуніна, та найбільше - кубанці полковника А.Шкура́. На початку 1917 р. останні знаходилися на Румунському фронті, але невдовзі були передислоковані на Кавказ. Оскільки 4-та російська армія під час запланованого наступу мала діяти в карпатських передгір'ях, ґенерал О.Рогоза справді міг відчувати потребу в маневреному партизанському відділові, здатному використати умови місцевості для завдання максимальної шкоди австро-німецьким військам.

9 липня 1917 р. штаб 4-ї армї видав розпорядження про фрормування 1-го Українського партизанського загону, командиром якого було призначено О.Сахна-Устимовича ${ }^{17}$. Він не приховував намірів щодо відродження українського війська та навіть в офіційних документах називав свій підрозділ "Гайдамацьким куренем запорізького козацтва» ${ }^{18}$. Замість звання ротмістра О.Сахно-Устимович на козацький манер іменував себе підосавулом.

Хоча загін мав формуватися в Одесі, перший набір добровольщів було вирішено здійснити в Києві. У липні 1917 р. тут склалася вибухонебезпечна ситуація: близько 5 тис. вояків-українців відмовлялися вирушати на фрронт і всупереч заборонам російської влади створили 2-й Український полк ім. П.Полуботка ${ }^{19}$. 3 острахом очікуючи збройних заворушень у місті, військове командування шукало шляхів бодай частково “розвантажити» Київ від полуботківців. Упродовж кількох днів О.Сахно-Устимович зібрав на етапнорозподільчих пунктах міста близько 1 тис. добровольців, котрі зголосилися на

14 ГАРФ. - Ф.6978. - Оп.1. - Д.512. - Л.1.

15 Український національно-визвольний рух... - С.376.

16 ГАРФ. - Ф.5881. - Оп.1. - Д.583. - Л.58, 180.

17 Российский государственный военно-исторический архив (далі - РГВИА). - Ф.1837. Оп.1. - Д.454. - Л.5, 7, 62.

18 Там же. - Л.20, 62.

19 Там же. - Ф.2067. - Оп.2. - Д.446. - Л.153. 
формування одеського загону ${ }^{20}$. Швидше всього, серед них було чимало полуботківців, які вважали за краще перенести організаційну роботу зі створення українських частин до Одеси. Адже якщо формування полку ім. П.Полуботка було заборонено командуванням під загрозою переслідувань, то створення одеського загону відбувалося цілком легально, за офіційним дозволом російської влади.

13 липня 1917 р. командувач Румунського фронту генерал Д.Щербачов наказав перекинути Український партизанський загін із Києва до Одеси з тим, щоб після одержання зброї та завершення формування відправити цей підрозділ до складу 4-ї армії. Уже наступного дня загін О.Сахна-Устимовича вирушив до Одеси, куди й прибув 18 липня ${ }^{21}$.

За початковим планом, 1-й Український партизанський загін мав бути кінним підрозділом. Та оскільки в Одесі не знайшлося потрібної кількості коней, верховний головнокомандувач наказав переформувати його за зразком 2-батальйонного Латиського полку з деякими змінами штату ${ }^{22}$. Відповідно до розпорядження, Український партизанський загін мав налічувати 2500 вояків, 70 оріцерів, 3 чиновників ${ }^{23}$. До складу кожного батальйону входили 4 піхотних роти, кулеметна, розвідувальна, зв'язкова, кінно-підривна й господарська команди.

Оскільки О.Сахно-Устимович мав дозвіл від командування Румунського фронту, штаб Одеського військового округу не чинив перешкод формуванню українського загону ${ }^{24}$. Гайдамакам відвели місце в казармах у південному передмісті. Розташований поблизу пустир був зручним місцем для вишколу. Сучасник так описував табір гайдамаків під Одесою:

«Між деревами густо порозкидались кущі, під якими стомлені козаки поклалися спати. Там на пеньку, в холодочку, сидить козак, похилившись; над ним свійський голяр із "оселедцем" голить, залишаючи і йому “оселедця". Тут компанія, як видно, новоприбулих, підстеливши шинелю, закусюе, чим Бог послав, озираеться на всі боки, ділячись враженнями. Тут же недалеко розкинуті шатра звичайного російського таборового зразку вперемішку з маленькими походними, до котрих туляться імпровізовані намети з плахт, із килимів та кавалків хатнього полотна. Між шатрами в порядкові, в "козлах" стоять рушниці, шаблі, кулемети; біля них походжае суворо варта... Чути пісню "Ми гайдамаки, всі ми однакі”, - це повертаеться сотня з навчання... Обличчя освітлені внутрішнім сяйвом твердості, рішучості та гордості від свідомості, що вони - піонери великого діла - відбудови України. Всі вони - і старшина, й козаки - добровольці; прийшли сюди, маючи на думці тільки боронити свій край, якого вже починає охоплювати пожежа анархії ${ }^{25}$.

20 РГВИА. - Ф.1837. - Оп.1. - Д.454. - Л.27.

${ }_{21}$ Там же. - Л.1, 5, 20, 27.

22 Там же. - Л.65.

${ }_{23}$ Там же. - Л.79.

${ }^{24}$ ГАРФ. - Ф.5881. - Оп.1. - Д.583. - Л.180.

25 Янчевський М. Зі споминів // За державність. - Зб.2. - Каліш, 1930. - С.142. 
1-й Український партизанський загін створювався на засадах суворої військової дисципліни. У підрозділі не допускалося жодної політики, заборонялася діяльність виборних організацій ${ }^{26}$. «золяція в таборах під Одесою, фрільтрування особового складу, вишкіл і облаштування цих частин були добре відомі», - свідчив знаний діяч українського військового руху М.Удовиченко 27. Член Одеської української військової ради Г.Гришко у спогадах так змалював засади організації гайдамацького підрозділу:

«Себто, кожний вояк, підписавши відповідний лист-декларацію, тим корився всім вимогам статуту. А вони були такі: коритися начальникові, ніяких комітетів у частинах, ніякої участі в політичному житті, поки вояк перебуває на службі, не допускати в частинах ніякої агітації, а тим самим агітаторів. Всякі спроби агітаторів прослизнути в частину, хоч би під виглядом культурно-освітнього робітника, розбивалися о цензуру. Коли хтось хотів зробити доклад, прочитати лекцію, то він мусів був подати це на письмі до команди куреня. Призначений цензор-старшина перечитував це і щойно тоді команда куреня давала дозвіл або відхиляла пропозицію. Причин заборони докладчикові ніколи не подавали. Воякам рішуче заборонялося виходити до міста без одповідного дозволу команди» ${ }^{28}$.

Одностроєм для гайдамаків стали черкески, які О.Сахно-Устимович спеціально замовив на Кубані ${ }^{29}$. Імовірно, він намагався у зовнішньому вигляді своїх бійців наслідувати відомий кубанський загін А.Шкура́. У будь-якому разі, така уніформа імпонувала багатьом гайдамакам, які цінували символи козацької традиції. Іншою характерною відзнакою українських партизанів стали червоні шлики ${ }^{30}$. Невипадково член президії ради робітничих депутатів Г.Ачканов згадував про подібний до давніх запорожців одяг одеських гайдамаків ${ }^{31}$. Проте одностайності зовнішнього вигляду вояків удалося досягти не відразу. Описуючи свої перші враження від відвідин гайдамацького табору, сучасник відзначав: «Повноту картини доповняють козаки і старшина в старовинних козацьких строях, у черкесках, вишиваних сорочках. Але ще не всі здолали привести себе до такого вигляду. Більшість одягнута в російські “гімнастьорки” та захисного кольору шаровари» ${ }^{32}$.

Чисельність українського загону стрімко зростала. Уже наприкінщі липня 1917 р. до лав гайдамаків перейшли 6 офріцерів і значна група солдатів 46-го i 48-го запасних полків, а згодом і музична команда 40-го запасного полку ${ }^{33}$. Ледь не щодня зголошувалися вояки, які нелегально залишали свої частини. Як свідчив Г.Гришко, гайдамаки «почали поступнево приймати перебіжчиків

${ }^{26}$ РГВИА. - Ф.1837. - Оп.1. - Д.454. - Л.22.

27 Див.: ГАРФ. - Ф.5881. - Оп.1. - Д.583. - Л.180.

28 Гришко Г. 1917 рік в Одесі... // Розбудова нації. - 1930. - Ч.9/10 (33/34), - С.240.

${ }^{29}$ ГАРФ. - Ф.5881. - Оп.1. - Д.583. - Л.180.

30 Див.: Янчевський М. Зі споминів. - С.144.

31 Ачканов Г. Очерки Февральской и Октябрьской революции в Одессе. - Одесса, 1927. - С.21.

32 Янчевський М. Зі споминів. - С.142.

${ }^{33}$ РГВИА. - Ф.1837. - Оп.1. - Д.454. - Л.11-12, 16. 
із інших частин» ${ }^{34}$. Станом на 31 серпня 1-й Український партизанський загін мав 8 пластунських сотень по 160 чол., 2 кінні сотні (утім без коней) по 160 чол., кулеметну команду (16 кулеметів) і відділ зв'язку. Таким чином, загін налічував 38 офіцерів і понад 1600 вояків ${ }^{35} .7$ вересня 1917 р. перший батальйон, який отримав назву 1-го Гайдамацького куреня запорізького козацтва, завершив свое формування ${ }^{36}$. Начальник штабу Одеського військового округу генерал Н.Маркс у донесенні командуванню надзвичайно високо оцінював стан гайдамаків: «Названі вісім сотень партизанського загону згуртовані, організовані, пов’язані дружньо і спаяні залізною дисципліною» ${ }^{37}$.

Хоча російському командуванню довелося з різних причин відмовитися від запланованого наступу на Румунському фронті, гостра нестача військ на позиціях змусила ґенерала О.Рогозу вже 24 серпня 1917 р. клопотатися про відправку 1-го Українського партизанського загону до складу 4-ї армії. За наказом Д.Щербачова, підрозділ мав вирушити на фронт у неповному складі, залишивши кінні сотні в Одесі. Для поповнення загону при 34-й запасній бригаді створювався батальйон (у складі 4 рот), куди належало приймати винятково добровольців ${ }^{38}$.

Непоінформованість армійського командування про стан організації 1-го Українського партизанського загону швидко з'ясувалася, коли О.СахноУ стимович сповістив про відсутність у його команді другого батальйону та кінних підрозділів. 12 вересня 1917 р. Д.Щербачов дозволив затримати загін в Одесі ще на два тижні. Процедуру формування партизанів було дещо змінено: тепер новобранці мали пройти вишкіл у складі запасного батальйону (створеного 18 вересня), перш ніж поповнити лави вже існуючих підрозділів ${ }^{39}$.

На тлі стрімкого занепаду військової дисципліни в частинах одеського гарнізону гайдамаки зберігали майже взірцевий порядок. За свідченням М.Удовиченка, «військова влада в Одесі була в захваті від здорового духу i дисципліни серед українців» ${ }^{40}$. Новопризначений головний начальник Одеського військового округу генерал П.Феліцин не приховував, що вважае український загін единою надійною збройною силою в місті. Ідучи назустріч побажанням національних організацій, він уживав в офіційних документах назву «1-й Гайдамацький курінь запорізьких козаків». Крім того, дав дозвіл на українізацію запасного кулеметного батальйону. Коли ж наприкінці вересня 1917 р. з'явилося розпорядження командування про відправку українських партизанів до Баку, П.Феліцин попрохав дозволу «тимчасово затримати відправку названого загону хоча б на два тижні, оскільки це едина надійна військова частина, якою я розпоряджаюсь в Одесі» ${ }^{41}$. До генерала дослухались і гайдамаків було остаточно залишено охороняти лад в Одесі.

\footnotetext{
${ }^{34}$ Гришко Г. 1917 рік в Одесі... // Розбудова нації. - 1930. - Ч.9/10 (33/34). - С.239.

${ }^{35}$ РГВИА. - Ф.1837. - Оп.1. - Д.454. - Л.66.

${ }_{36}$ Там же. - Л.62; Д.459. - Л.33.

37 Див.: Там же. - Д.454. - Л.70.

38 Там же. - Л.36, 65.

39 Там же. - Л.71, 95 об.

${ }^{40}$ ГАРФ. - Ф.5881. - Оп.1. - Д.583. - Л.58.

${ }^{41}$ РГВИА. - Ф.1837. - Оп.1. - Д.454. - Л.107.
} 
За свідченням представників російської влади, саме український загін восени 1917 р. ніс вартову службу на одеських вулицях ${ }^{42}$. Гайдамацькі підрозділи також забезпечували правопорядок в околицях міста. Так, у середині жовтня 400 українських вояків із 4 кулеметами взяли участь у приборканні солдатських бешкетів у Тирасполі ${ }^{43}$. 11 жовтня головний начальник ОВО наказав підготувати в Катеринославі приміщення для чотирьох сотень гайдамацького загону і стількох же навчальних команд ${ }^{44}$. «Шаб округи, що досі встромляв нам палки в колеса, тепер став сам звертатися до нас про допомогу, щоб установити порядок не тільки в самій Одесі, але й в цілій окрузі, - згадував Г.Гришко. - І ось почали посилати наші курені всюди, де тільки треба було встановити спокій та лад: до Катеринославу, Бахмачу, Херсону, Знаменки й т.Д. ${ }^{45}$.

На початку жовтня 1917 р. Український військовий ґенеральний комітет (УВІК) при Центральній Раді делегував для керівництва військовим рухом в Одесі свого представника - підполковника В.Поплавка ${ }^{46}$. А вже 11 жовтня генерал П.Феліцин видав наказ, яким окреслив організацію гайдамацьких підрозділів:

«Для об'єднання і командування українськими частинами округу, аж до затвердження штатів української запасної бригади, покладаю на підполковника залізничних військ Поплавка обов’язки командира бригади по відношенню до гайдамацького запасного куреня, запасного кулеметного батальйону й гайдамацького Запорізького куреня. Підполковникові Поплавку приступити до виконання покладених на нього обов'язків із цього числа та приступити до фрормування тимчасового штату бригади» ${ }^{47}$.

Окрім того, у середині жовтня 1917 р. зі ставки верховного головнокомандувача надійшов дозвіл на організацію у складі Українського партизанського загону двох кінних сотень ${ }^{48}$. Станом на 14 жовтня гайдамацький загін за списком налічував 3565 вояків при 94 офріцерах і 3 чиновниках. Натомість у наявності було 76 офіцерів, 3 чиновника й 3324 вояка ${ }^{49}$. Фактично штат 1-го Українського партизанського загону було перевищено. 18 жовтня 3 вояків, які залишили лави запасного куреня, розпочалося фрормування 2-го Гайдамацького куреня запорізького козацтва у складі чотирьох пластунських і однієї кінної сотень. Понад 800 осіб залишилися в лавах 1-го запасного гайдамацького куреня ${ }^{50}$. За повідомленням військового комісара при штабі ОВО М.Харита, на початку листопада 1917 р. гайдамацький загін в Одесі мав уже близько 5 тис. чол. ${ }^{51}$

42 Український національно-визвольний рух... - С.879.

${ }_{43}$ РГВИА. - Ф.366. - Оп.1. - Д.100. - Л.200, 207.

${ }_{44}$ Там же. - Ф.1837. - Оп.1. - Д.431. - Л.43.

45 Гришко Г. 1917 рік в Одесі... // Розбудова нації. - 1930. - Ч.9/10 (33/34). - С.240.

${ }_{46}$ РГВИА. - Ф.366. - Оп.2. - Д.233. - Л.104.

47 Там же. - Ф.1837. - Оп.1. - Д.459. - Л.64.

48 Там же. - Д.454. - Л.80.

49 Там же. - Л.79.

50 Там же. - Ф.1837. - Оп.1. - Д.431. - Л.185; Д.459. - Л.118.

51 Український національно-визвольний рух... - С.879. 
Зважуючи можливість відправки гайдамаків на Румунський фрронт, Одеська українська військова рада клопоталася, аби загін був направлений до лав 9-ї армії, де були українізовані військові з'єднання ${ }^{52}$. Водночас І.Луценко запропонував командуванню округу використати досвід гайдамацького формування для створення українських частин в інших містах Причорномор'я. 29 жовтня 1917 р. військова рада представила ґенералові Н.Марксу, який змінив П.Феліцина на посаді головного начальника ОВО, проект організації п’яти куренів 2-батальйонного складу в Бірзулі, Херсоні, Єлисаветграді, Олександрівську, Кривому Розі й ще двох куренів - кожен у складі трьох батальйонів - у Катеринославі та Сімферополі ${ }^{53}$. I хоча цей проект не було реалізовано, а створення національних частин на півдні України пішло власним шляхом, успішна організація гайдамацького загону в Одесі мала величезне значення для розгортання українського військового руху в регіоні.

1 листопада 1917 p. Н.Маркс доповідав вищому командуванню: «Український рух в окрузі сильно розвивається» ${ }^{54}$. Невідрадна картина цілковитого розвалу російських частин одеського гарнізону підштовхувала генерала Н.Маркса до співпраці з українськими військовими організаціями. 4 листопада він наказав підпорядкувати 1-й Український партизанський загін і 1-й Український запасний батальйон членові УВІК підполковникові В.Поплавку, поклавши на нього права командира бригади й обов’язки щодо подальшого формування частин ${ }^{55}$. Тим самим Н.Маркс фрактично підтвердив розпорядження свого попередника та забезпечив організаційно-правові передумови для створення в Одесі нових українських частин.

Глибока суспільна криза, що охопила країну восени 1917 р., наклала свій відбиток на політичну ситуащію у Причорномор’і. Серед багатонащіонального населення Одеси поширювалися чутки про наміри української військової ради захопити владу в місті ${ }^{56}$. На вулицях Одеси почастішали сутички гайдамаків із робітничою червоною гвардією. Звичним явищем стали провокації на грунті міжнаціональної ворожнечі. Ось як описувала одеська преса один із таких інцидентів:

«Школі прапорщиків провокаційним шляхом дали знати, ніби на них йдуть кінні гайдамаки. Водночас у гайдамацький курінь повідомили, що проти них виступають зі школи прапорщиків. Негайно біля школи вишикувалась сторожова охорона 3 вихованців школи, а назустріч юнкерам вийшли кінні гайдамаки. О 10 год. вечора, коли ця зустріч відбулася, ледь не сталося справжне зіткнення. Обидві сторони обмінялись кількома пострілами - на щастя, без наслідків для тих чи інших жертв провокації. I незважаючи на те, що якийсь автомобіль у той же час обстріляв гайдамацькі казарми, офіцерам з обох сторін вдалося приступити до перемовин і з'ясувати непорозуміння» ${ }^{57}$.

${ }_{52}$ РГВИА. - Ф.1837. - Оп.1. - Д.454. - Л.81.

53 Там же. - Д.459. - Л.121-123.

54 Там же. - Ф.366. - Оп.1. - Д.100. - Л.1.

${ }_{55}$ Там же. - Ф.1837. - Оп.1. - Д.459. - Л.96.

56 Див.: Центральний державний архів вищих органів влади та управління України (далі ЦДАВО України). - Ф.1705. - Оп.1. - Спр.7. - Арк.213-213 зв.; РГВИА. - Ф.366. - Оп.1. - Д.100. - Л.101.

57 Партизан. Вино, провокация, погромы // Одесские новости. - 1917. - 12 октября. - №10540. - С.4. 
Аби запобігти подібним провокаціям, на вулицях міста було запроваджено спільне патрулювання гайдамаків, міліціонерів та військовиків.

Відлунням петроградського перевороту стала спроба одеських більшовиків проголосити в місті радянську владу. Але подібні намагання зустріли спротив із боку різних політичних сил, у тому числі й українських організацій. При цьому І.Луценко та інші керівники Одеської української військової ради вважали, що падіння Тимчасового уряду відкриває можливості для створення національного війська й утвердження української державності. 8 листопада 1917 р. на українському з’їзді в Одесі представник гайдамацьких частин промовисто заявив: «Маю шаблю в руці-ще не вмерла Україна!» ${ }^{58}$. А в ніч з 14 на 15 листопада підполковник В.Поплавко оголосив зібраним у штабі ОВО воєначальникам про перехід усієї повноти влади в Україні до Центральної Ради. Тимчасовим головним начальником округу В.Поплавко призначив генерала Ю.Слчанинова - начальника розквартированої поблизу Одеси 12-ї кавалерійської дивізії, який погодився виконувати накази української влади. Іенерал Н.Маркс не зважився чинити опір. 15 листопада Ю.Єлчанинов уже приймав урочистий парад українських частин одеського гарнізону, а наступного дня генеральний комісар військових справ України С.Петлюра підтвердив його призначення на посаду головного начальника ОВО 59 . Фактичним керівником Одеського військового округу став колишній член УВІК підполковник В.Поплавко, призначений комісаром при штабі ОВО.

Більшовицька загроза спонукала революційні організації в Одесі до порозуміння з урядом Української Народної Республіки. Тимчасовий обласний революційний комітет, створений на паритетних засадах із представників рад, виконкому Румунського фрронту, Чорноморського фрлоту й Одеської області (Румчерод) та українських організацій, підпорядкувався урядові УНР 60 . Зі свого боку, представники української влади намагались забезпечити співпрацю 3 органами «револющійної демократії». Зокрема ґенерал Ю.Єлчанинов не заперечував, щоб посаду коменданта міста обійняв член президії ради солдатських депутатів більшовик Іур'єв ${ }^{61}$. I хоча пристрасті довкола політичних питань не вщухали, до збройних зіткнень між опонентами все ж не дійшло.

Правопорядок в Одесі підтримували українські частини. Підосавул О.Сахно-Устимович у цей час залишив гайдамацький загін, а підполковник В.Поплавко був призначений комісаром при штабі ОВО. Відтак командиром української бриґади в листопаді 1917 р. став полковник М.Мазуренко. Колишній командир запасного полку, він спершу ставився неприхильно до українізації, але після листопадової зміни влади перейшов на українську службу 62.

${ }_{58}$ Ив. Г. Украинский съезд // Там же. - 26 октября. - №10552. - С.3.

59 Розпорядження С.В.Петлюри // Робітнича газета. - 1917. - 4 листопада. - №176. - С.2. Див. також: Приказ украинским войскам Одесского гарнизона // Одесские новости. - 1917. -2 ноября. - №10558. - С.3; Аp. Украинизация Одессы и округа // Там же. - 3 ноября. - №10559. - С.2.

${ }^{60}$ ЦДАВО України. - Ф.4195. - Оп.1. - Спр.1. - Арк.4; Українська Центральна Рада: Документи і матеріали: У 2 т. - Т.1. - К., 1996. - С.410.

${ }_{61}$ Ачканов $Г$. 3 спогадів про Лютневу і Жовтневу революції в Одесі // У дні Жовтня: Спогади учасників боротьби за владу Рад на Україні. - К., 1987. - С.405.

62 Гришко Г. 1917 рік в Одесі... // Розбудова нації. - 1930. - Ч.7/8 (31/32). - С.180-181, 186. 
Користуючись зняттям адміністративних перепон, вояки-українці одеського ґарнізону організовано переходили до лав гайдамацького загону. Наприклад, саме так учинили українці з 40-го запасного полку на чолі з підосавулом Ю.Мацаком. Для поповнення одеських гайдамаків командування округу залучало й військові частини з інших міст Причорномор'я. 24 листопада 1917 р. ґенерал Ю.Єлчанинов розпорядився начальникові 168-ї команди виздоровців в Слисаветграді та командирові 48-го запасного полку в Оріховому «приступити до формування гайдамацьких пластунських сотень для запасного гайдамацького куреня, що знаходиться в Одесі ${ }^{63}$. Командирові 277-го запасного полку (Акерман) також було наказано направити вояків-українців до національних частин ${ }^{64}$.

На початку грудня 1917 р. військовий секретар УНР С.Петлюра розробив план щодо організації українського війська на півдні України. Відповідно до його вказівок, генерал Ю.Слчанинов 7 грудня видав наказ про реорганізацію українських підрозділів в Одесі. Зокрема на базі 1-го Гайдамацького куреня створювався 1-й Гайдамацький пластунський полк, а запасний гайдамацький курінь належало переформувати у 2-й Гайдамацький пластунський полк. Кожен полк мав складатися з трьох батальйонів. Крім того, зі складу 1-го Гайдамацького куреня планувалося виділити кінний дивізіон, який згодом мали розгорнути в Гайдамацький кінний полк у складі чотирьох сотень. Розпочалося й формування 1-ї Української легкої батареї ${ }^{65} .12$ грудня Ю.Слчанинов призначив командиром 1-го Гайдамацького кінного полку підполковника В.Продьма, а командиром 1-ї Української легкої батареї - штабскапітана С.Комірного ${ }^{66}$.

Аби укомплектувати гайдамацькі полки, полковник М.Мазуренко скасував ретельний відбір добровольців і дозволив приймати до частин усіх бажаючих. Проте серед поповнень, які надійшли до бригади впродовж листопада 1917 р., виявилося чимало прихильників «демократизації» війська. Один 3 українських офіцерів згадував: «І що ж ми почали помічати? Почалися серед козаків балачки, що так не мае бути, що по всіх частинах е ради, а в нас їх нема. Старшини тут, мовляв, що хочуть, те й роблять, а козаки не мають ніякого голосу. Далі почали мріяти про те, що треба завести в себе ради, як це було на старому Запоріжжі, старшин, мовляв, треба вибирати. Почалася ось так сварка поміж самими козаками» ${ }^{67}$. На початку грудня 1917 р. в гайдамацьких частинах уже з'явилися виборні ради.

Окрім гайдамацької бриґади, в Одесі урядові УНР підпорядкувалися також 1-ша школа прапорщиків й авіаційна школа. Українізувалися 1-й Одеський український авіазагін, 44-та окрема телеграфна рота, сформовані з 460-ї й 479-ї ополченських дружин караульні батальйони ${ }^{68}$. На прохання

${ }_{63}$ РГВИА. - Ф.1837. - Оп.1. - Д.431. - Л.116.

64 Там же. - Л.161.

65 Там же. - Д.466. - Л.19, 76.

66 Там же. - Л.83.

67 Гришко Г. 1917 рік в Одесі... // Розбудова нації. - 1930. - Ч.9/10 (33/34). - С.241.

68 В Одесі // Козацька думка. - 1917. - 1 грудня. - Ч.4. - С.4; РГВИА. - Ф.2085. - Оп.2. Д.128. - Л.10; Ф.1837. - Оп.1. - Д.466. - Л.141, 328. 
В.Поплавка, командувач Румунського фронту Д.Щербачов наказав передислокувати до Одеси 270-й запасний полк, який стояв у Вапнярці та значною мірою складався з українців ${ }^{69}$. Але внаслідок суперечливих наказів командування ця військова одиниця ще тривалий час залишалася на Поділлі. Та поки 270-й запасний полк нарешті прибув до Одеси в місті спалахнуло збройне зіткнення з прихильниками радянської влади.

Приводом до конфлікту стала заборона українською владою у середині грудня 1917 р. організації воєнної експедиції на Дон проти козацьких частин О.Каледіна. Послідовно засуджуючи розпалювання громадянської війни, українська військова рада роз'яснила, що бажаючі воювати 3 каледінцями можуть вирушити на Дон у приватному порядку, але не організованими загонами. Це викликало гостре невдоволення одеських прихильників радянської влади, які створили військово-революційний штаб і почали готувати повстання. Хоча переважна більшість гарнізону дотримувалася нейтралітету, борців за «пролетарську революцію» підтримували загони червоної ґвардії, створені на заводі Російського товариства пароплавства й торгівлі, інших підприемствах. На світанку 13 грудня червоногвардійці почали займати центральні квартали та проходи в порт. До вечора кількасот озброєних робітників зосередилися біля Воронцовського палацу на Миколаївському бульварі, де знаходився виконком ради робітничих депутатів ${ }^{70}$.

Приборкання заколотників стало першим бойовим хрещенням гайдамацької бриґади. Уранці 14 грудня 1917 р. за наказом ґенерала Ю.Єлчанинова у центр міста ввійшов 2-й Гайдамацький пластунський полк. Розігнавши червоногвардійську варту, гайдамаки зайняли вокзал, телефонну станцію та почали просуватися в бік оперного театру. Невдовзі на вулицях залунали постріли. У сутичці біля будинку колишнього одеського градоначальства смертельного поранення зазнав начальник штабу червоної гвардії М.Кангун. Після цього перестрілки між гайдамаками й червоногвардійцями спалахнули на вул. Пушкінській, у районі Миколаївського бульвару, біля міського театру. Вокзал, телефонна станція й інші пункти у центрі міста по декілька разів переходили з рук у руки ${ }^{71}$. Зрештою підрозділи 2-го Гайдамацького пластунського полку закріпилися в районі вокзалу, Куликового поля, Пушкінської, Канатної й Малої Фонтанної вулиць. Розосередившись у центрі міста, гайдамаки однак втратили чисельну перевагу на окремих бойових ділянках. Скориставшись цим, червоногвардійці перейшли в наступ у районі Великої й Малої Арнаутських вулиць. Українські вояки змушені були відійти на Куликове поле, коли на допомогу їм прибув підрозділ 1-го Гайдамацького пластунського полку. Після цього розпочалася контратака. Підполковник М.Янчевський згадував: «Наступ був гвалтовний. Гайдамаки до полону червоноІвардійців майже не брали. До рук гайдамаків дісталося багато мушкетів і

69 РГВИА. - Ф.1837. - Оп.1. - Д.466. - Л.7, 14.

70 Див.: Ковальчук М. Битва двох революцій: Перша війна Української Народної Республіки з радянською Росіею: 1917-1918 pp. - Т.1. - К., 2015. - С.136-137.

${ }_{71}$ Там само. - C.138-140. 
до десятка кулеметів» ${ }^{72}$. До вечора гайдамаки витіснили червоногвардійців у портовий район. «Рештки червоної гвардії, що відступали під прикриттям ночі до свого штабу, відступили до Ропіта, - згадував член загальноміського штабу червоної гвардії А.Броневий. - Відступати далі було нікуди. У штабі червоної гвардії було залишено кількох надійних товаришів, яким було дано завдання висадити його в повітря в разі, якщо його буде зайнято гайдамаками» ${ }^{73}$.

Успішні дії гайдамаџьких частин дозволили представникам української влади розпочати переговори з керівниками військово-революційного штабу про припинення вуличних боїв. Окрім того, очільників повстання зробило поступливішими прибуття до Одеси п'яти українських ескадронів стрілецького полку 8-ї кавалерійської дивізії (10 офіцерів, 1650 вояків) ${ }^{74}$. Цей підрозділ без дозволу командування вирушив із Румунського фронту на допомогу одеським гайдамакам. 15 грудня 1917 р. ворогуючі сторони уклали домовленість, згідно з якою влада в місті переходила до колегіального органу, створеного 3 представників рад, Румчероду, української військової ради й червоної гвардії. Увечері того ж дня бойові дії припинилися. За наказом Ю.Слчанинова, гайдамацькі підрозділи поступово відійшли на південну околицю міста. За даними української влади, у боях загинули 4 військовослужбовців ${ }^{75}$.

Невдовзі після одеських подій гайдамацькі частини ліквідували спробу більшовицького перевороту в Миколаєві. Зокрема 22 грудня 1917 р. на допомогу місцевій українській раді довелося відправити підрозділи 2-го Гайдамацького пластунського полку. Спільно з частинами миколаївського гарнізону гайдамаки взяли під контроль становище в місті. У сутичці з українськими вояками загинув начальник місцевої червоної гвардії А.Золотухін ${ }^{76}$. Уранці 29 грудня гайдамакам довелося витримати справжній бій на вулицях міста, але прибуття до Миколаєва решти підрозділів 2-го Гайдамацького пластунського полку змусило червоногвардійців припинити збройну боротьбу ${ }^{77}$. Заявивши про готовність до порозуміння, більшовики делегували своїх представників до військово-революційного комітету, що мав стати найвищим органом влади в Миколаєві. Після того, як збройні сутички на вулицях міста вщухли, 2-й Гайдамацький пластунський полк повернувся до Одеси.

Формальне примирення між прихильниками й противниками українського уряду не могло приховати зростання політичної напруги в містах Причорномор'я. Соціальна й економічна нестабільність супроводжувалися поширенням анархї, безробіттям, продовольчою кризою. Загроза нових заворушень в Одесі стримувала Ю.Єлчанинова та В.Поплавка від відправки гайдамацьких частин проти радянських загонів В.Антонова-Овсієнка, які саме у

72 Янчевський М. Зі споминів. - С.147.

73 Броневой Ал. Октябрьские дни в Одессе (воспоминания бывшего красногвардейца штаба одесской рабочей красной гвардии) // Летопись революции. - 1927. - №5/6 (26/27). - С.256.

74 РГВИА. - Ф.2126. - Оп.1. - Д.663. - Л.12; Ф.2003. - Оп.1. - Д.683. - Л.206.

75 Ковальчук М. Битва двох революцій. - Т.1. - С.143.

76 Державний архів Миколаївської області. - Ф.П-4074. - Оп.1. - Спр.18. - Арк.4; Центральний державний архів громадських об’еднань України (далі - ЦДАГО України). - Ф.59. - Оп.1. Спр.789. - Арк.10; Спр.1533. - Арк.34, 36; Спр.1170. - Арк.63.

77 Ковальчук М. Битва двох революцій. - Т.1. - С.350-351. 
цей час розпочали наступ проти військ УНР на Катеринославщині. Крім того, українське командування не ризикувало ослабити одеський гарнізон перед загрозою ворожих дій із боку Чорноморського фрлоту, який підтримав радянський уряд.

Намагаючись позбутися збільшовичених елементів у військових частинах, генерал Ю.Єлчанинов 23 грудня 1917 р. наказав звільнити у відпустку всіх вояків неукраїнської національності на теренах ОВО. Це розпорядження призвело до масової демобілізації одеського гарнізону ${ }^{78}$. Після того, як чисельність деяких частин зменшилася втричі, ці формування вже не являли з себе жодної військової сили. Здійснювати ж агітаційну роботу серед гайдамаків одеські більшовики не мали змоги, оскільки, за красномовним свідченням одного 3 них, «серед більш-менш відповідальних працівників нашої партії в тогочасній Одесі жоден товариш не володів українською мовою» ${ }^{79}$.

Демобілізація не торкнулася гайдамацьких частин, чисельність яких стрімко зростала. Станом на 29 грудня 1917 р. 1-й і 2-й Гайдамацькі пластунські полки налічували 7633 вояки при 334 офіцерах (із них 1918 числилися хворими, перебували у відпустках тощо). Бригада мала на озброєнні 10771 рушницю і 83 кулемети ${ }^{80}$. Полками у цей час командували, відповідно, штабс-капітани Осмоловський та Орлов ${ }^{81}$. Коли ж до Одеси прибув 270-й запасний полк, його було реорганізовано у 3-й Гайдамацький пластунський. Прагнучи зосередити в місті якомога більшу кількість українських військ, командування ОВО навіть прохало генерала Д.Щербачова надіслати до Одеси 4-й Запорізький полк зі складу 9-ї армії Румунського фрронту ${ }^{82}$.

Наприкінці грудня 1917 р. розпочалося формування 1-ї Одеської української дивізії. Майже всі частини цього військового з'єднання дислокувалися в Одесі - за винятком 4-го Гайдамацького пластунського полку, сформованого в Акермані на базі 277-го запасного полку. Окрім уже наявних трьох пластунських й одного кінного гайдамацьких полків, в Одесі створювалися дивізійна артилерія та кулеметна частина. Для формування гарматної бригади було використано 132-гу, 133-тю, 134-ту, 135-ту, 136-ту й 137-му позиційні легкі батареї, призначені в російській армії для ведення вогню по аеропланах $^{83}$. Командиром гарматної бригади став колишній командувач 5-го запасного гарматного дивізіону полковник Р.Столбовський, який 4 січня 1918 р. приступив до виконання своїх обов'язків. 1-й гарматний дивізіон очолив капітан Гунченко, 2-й - капітан Каменський ${ }^{84}$. Український кулеметний полк (командир - штабс-капітан Ю.Мацак) створювався на базі розформованого Кольтівського кулеметного полку ${ }^{85}$.

${ }^{78}$ ГАРФ. - Ф.130. - Оп.1. - Д.75. - Л.27; Гавен Ю. Октябрь в Крыму // Октябрь на фрронте: Воспоминания. - Москва, 1967. - С.289.

79 Державний архів Одеської області. - Ф.П-2. - Оп.1. - Спр.1147. - Арк.3.

80 РГВИА. - Ф.1837. - Оп.1. - Д.466. - Л.212.

81 Там же. - Д.431. - Л.47.

82 Там же. - Д.466. - Л.99.

83 Там же. - Л.104.

${ }^{84}$ Там же. - Л.243, 284, 327 об.; Д.431. - Л.47.

85 Там же. - Д.431. - Л.47; Д.466. - Л.301, 327 об. 
Начальником Одеської дивізії було призначено генерал-майора Васильева, але за його відсутності обов'язки начдива виконував командир гайдамацької бригади М.Мазуренко. Схожим чином обов'язки начальника штабу дивізії виконував капітан В.Змієнко - оскільки призначений на цю посаду підполковник Яндоловський не прибув на місце служби ${ }^{86}$. Утім молодий офріцер виявився палким патріотом і досвідченим штабним працівником. Згадуючи про обставини розбудови збройних сил УНР на початку 1918 р., співробітник українського Генерального штабу М.Удовиченко відзначав:

«З цього часу до мене стали доходити звістки про помітну в
одеських українських колах постать молодого капітана Змієнка,
котрий своїми сміливими й рішучими заходами надавав бадь--
рості українським частинам. Коли командував гайдамацькою
бригадою полковник Мазуренко, то мимоволі складалося вра-
ження, що військово-революційною боротьбою в широкому зна-
ченні цього слова керував хтось інший і мені кожного разу, при
спробах знайти цей керівний осередок, доводилося чути про ши-
року національну діяльність капітана Змієнка»87.

Старшим ад’ютантом з оперативної частини у штабі Одеської дивізії було призначено штабс-капітана Станіславського, старшим ад’ютантом з інспекторської частини - штабс-капітана Адаменка ${ }^{88}$.

Провідний діяч більшовицького партосередку в Одесі стверджував у спогадах, що «гайдамаки доволі тісно згрупувалися довкола свого жовто-блакитного стягу» ${ }^{89}$. Насправді стан гайдамацьких частин залишав бажати кращого. Полковник М.Омелянович-Павленко спостеріг у 1-й Одеській дивізії брак досвідчених кадрових офіцерів ${ }^{90}$. Звичним явищем стала недовіра вояків-українців до старшин, чимало з яких були лише вимушеними попутниками національного руху. Відсутність системи відбору під час прийому вояків призвела до появи в лавах дивізії розпропагованих «елементів». Цілковито збільшовиченими виявилися вояки сформованих у Петрограді кулеметних підрозділів, які поповнили лави Одеської дивізії. Уже на початку січня 1918 р. М.Мазуренко доповідав Ю.Слчанинову:

«Останнім часом настрій частин ввіреної мені дивізії погіршився. Вплив прибулих з Петрограду більшовицько-налаштованих людей, у зв’язку з безперервно зростаючим внаслідок звільнення, некомплекту людей, що ускладнюе і без того надзвичайно важку, за числом караульну службу, створюе хвилювання в частинах. Люди починають непоштиво ставитися до керівних осіб... Караульна служба несеться невірно: люди залишають караули, не очікуючи зміни, яка своєчасно ніколи не прибуває... Загалом можна сказати, що більшовизм потроху починає

${ }^{86}$ ЦДАВО України. - Ф.647. - Оп.1. - Спр.1. - Арк.19 зв.

87 ГАРФ. - Ф.5881. - Оп.1. - Д.583. - Л.276.

88 РГВИА. - Ф.1837. - Оп.1. - Д.431. - Л.47; Д.466. - Л.327 об.

89 Юдовский В. Одесский военно-революционный комитет 1918 года // Каторга и ссылка. 1932. - №11/12. - C.242.

90 Омелянович-Павленко М. Спогади командарма (1917-1920). - К., 2007. - С.56. 
просочуватися і в українські частини, і боротьба з цим явищем надзвичайно важка» ${ }^{91}$.

На урядовому засіданні підполковник В.Поплавко так змальовував становище в Одесі: «Більшовизму вже нема, бо розпустили всіх вояків, хто походить не з України. Але замість цього росте більшовизм серед українського війська, більшовизм ширять ті українські частини, які прибули з Петрограда» ${ }^{92}$.

Більшовики та їхні попутники використали для зміцнення свого політичного впливу II з'їзд рад робітничих і солдатських депутатів Румунського фронту, Одеської області й Чорноморського флоту, який відбувся в Одесі на початку січня 1918 р. Делегати з'їзду переобрали Румчерод, забезпечивши більшість у його складі більшовикам і російським лівим есерам ${ }^{93}$. Президія Румчероду відразу ж створила військово-револющійний комітет (ВРК), головним завданням якого стала підготовка повстання проти української влади. Крім того, на з'їзді вперше заявила про себе група "українських соціал-демократів-більшовиків», які вже невдовзі розпочали агітацію відповідного змісту серед гайдамаків ${ }^{94}$.

Ariтаційна робота серед українських вояків, як згадував голова ВРК В.Юдовський, напрочуд швидко принесла свої плоди: «На засіданнях військовореволющійного комітету дедалі частіше почали з'являтися представники гайдамацьких низів, дедалі уважніше стали прислухатися “курені” до промов наших агітаторів» ${ }^{95}$. За свідченням іншого мемуариста, «чимало представників куренів заявили, що під час захоплення влади радою вони підтримають ради або принаймні будуть нейтральними» ${ }^{96}$. Один із керівників агітаційної роботи в лавах 1-ї Одеської дивізії стверджував, що у січні 1918 р. близько 2 тис. гайдамаків підтримували радянську владу ${ }^{97}$. Навіть якщо ця цифра перебільшена, переважна частина українських вояків на цей час схилялася до нейтралітету в політичних питаннях. «Там, де ми рахували по декілька тисяч вояків, було їх навіть неповні сотки, - свідчив Г.Гришко. - Виявилося, що чимало вояків було на відпустці, частина ж хорувала вже на більшовицьку пошесть, що ії занесли до наших частин різні агітатори» ${ }^{98} .17$ січня 1918 р. вояки кулеметних батальйонів відкрито заявили про підтримку радянської влади ${ }^{99}$. Досягнуті успіхи обнадіяли прихильників перевороту: «Маючи достатню вже кількість прибічників у лавах гайдамацьких куренів, ми вирішили будь-що організуватися так, щоб можна було за участі вірних нам частин зрештою захопити владу» ${ }^{100}$.

91 ЦДАВО України. - Ф.1705. - Оп.1. - Спр.7. - Арк.188-188 зв.

92 Українська Центральна Рада: Документи і матеріали. - Т.2. - С.65.

93 Базанов С. Борьба за власть в действующей российской армии (октябрь 1917 - февраль 1918 гг.). - Москва, 2003. - С.124; ЦДАВО України. - Ф.3156. - Оп.1. - Спр.16. - Арк.2 зв.

94 Держкавний архів Одеської області. - Ф.П-2. - Оп.1. - Спр.882. - Арк.9-10.

95 Юдовский В. Одесский военно-революционный комитет 1918 года. - С.243.

96 Тарасов П. От Февраля до Октября 1917 года // Старый большевик: Сборник. - 1933. №4 (7). - C.106.

97 Державний архів Одеської області. - Ф.П-2. - Оп.1. - Спр.1147. - Арк.5.

98 Гришко Г. 1917 рік в Одесі... // Розбудова нації. - 1930. - Ч.11/12 (35/36). - С.286-287.

99 Великая Октябрьская Социалистическая революция на Украине: Февраль 1917 - апрель

1918 гг.: Сборник документов и материалов: В 3 т. - Т.3. - К., 1957. - С.124-125.

100 Державний архів Одеської області. - Ф.П-2. - Оп.1. - Спр.882. - Арк.9. 
У ніч на 27 січня 1918 р. прихильники радянської влади взяли під свій контроль головні установи Одеси. Під орудою військово-революційного комітету виступило близько 1 тис. матросів, червоногвардійців і вояків. ВРК урочисто повідомив, що «влада в Одесі перейшла до рад робітничих, солдатських, матроських і селянських депутатів» ${ }^{101}$. Та вже ввечері того дня командування 1-ї Одеської дивізії в ультимативному порядку зажадало від ВРК і Румчероду звільнити державні установи, погодитися на підпорядкування штабу округу урядові УНР та створення в місті сощіалістичної (але не радянської) влади ${ }^{102}$. Коли ж заколотники відхилили ультиматум, вулиці Одеси знову перетворилися на арену бойових дій.

Як й очікували більшовики, переважна більшість гайдамаків оголосили нейтралітет у збройній боротьбі. Дві сотні 1-го й три сотні 2-го пластунських полків заявили, що виконуватимуть лише накази Румчероду ${ }^{103}$. Радянський мемуарист згодом стверджував, що 200-250 гайдамаків приедналися до більшовиків і повернули зброю проти своїх товаришів ${ }^{104}$. Сформований значною мірою з українців 12-й Охтирський гусарський полк, частина підрозділів якого дислокувалася в Одесі, також заявив про підтримку радянської влади. Як випливае зі спогадів учасників тих подій, на боці уряду УНР виступило не більше 1 тис. бійців.

На світанку 28 січня 1918 р. українські добровольці, вишикувавшись у лаву поблизу Сергієвського гарматного училища, вирушили в бік вокзалу. Після запеклої перестрілки з червоними, штаб ОВО було зайнято ${ }^{105}$. Член військової секції Румчероду Н.Павлов згадував: «Наступ гайдамаків був несподіваним. Румчерод, штаб червоної гвардії були повідомлені про це до відома утікачами окремими червоногвардійцями й матросами» ${ }^{106}$. Розгорнувшись на Куликовому полі та Французькому бульварі, українська артилерія почала обстрілювати ворожі позиції вглибині міста. Червоногвардійці й матроси вчинили запеклий опір гайдамакам у районі Базарної та Єврейської вулиць, на Олександрівському проспекті ${ }^{107}$. Учасник подій із радянського боку свідчив, що українські вояки «бились відчайдушно» ${ }^{108}$. Під натиском гайдамаків червоні змушені були залишити Велику Арнаутську й відступили до вул. Кондратенка.

У пригоді українським воякам стали броньовані машини 4-го панцерного дивізіону, доставлені наприкінці січня з Акермана ${ }^{109}$. Міські вулиці слугували зручними «трасами» для наступу броньовиків. Г.Гришко згадував: «Але коли ми пустили броневі авта з кулеметами, то справа пішла добре. На одному такому авті з двома кулеметами їздив я сам цілий день. Зброя та була для такої

101 Великая Октябрьская Социалистическая революция на Украине... - Т.3. - С.159.

102 Ультиматум украинского штаба // Одесский листок. - 1918. - 18 января. - №11. - С.1.

103 Большевики и гайдамаки // Там же. -15 января. - №10. - С.1.

104 Держкавний архів Одеської області. - Ф.П-2. - Оп.1. - Спр.1147. - Арк.6.

105 Братоубийственная война // Одесские новости. - 1918. - 19 января. - №10617. - С.1.

106 Державний архів Київської області. - Ф.Р-4823. - Оп.1. - Спр.28. - Арк.19.

107 Гражданская война: Сводка событий // Одесский листок. - 1918. - 19 января. - №12. - С.2;

Ив. Г. Из личных впечатлений // Одесские новости. - 1918. - 19 января. - №10617. - С.2.

108 Кривошеев А. Октябрь на Юге // Гражданская война: Материалы. - Т.II. - Москва, 1923. - C.121.

109 Державний архів Київської області. - Ф.Р-4823. - Оп.1. - Спр.28. - Арк.15; Украинские войска // Аккерманское слово. - 1918. - 6 января. - №1798. - С.4. 
війни цілковито незамінима. Було аж страшно дивитись зрештою, коли пішли в роботу обидва кулемети...» ${ }^{110}$.

Становище прихильників радянської влади стало критичним, але надвечір з акваторії Одеського порту їх підтримали вогнем далекобійної артилерії лінійні кораблі «Синоп» і «Ростислав». Підбадьорені червоні перейшли в контратаку. Жорстокі бої точилися на Олександрівському проспекті, Канатній, Пушкінській, Рішельєвській, Катерининській, Преображенській і частково Новорибній вулицях. «Українським частинам довелося відступити до вокзалу, який вони перетворили на фортецю. На дахах й у вікнах було встановлено кулемети і злива куль почала поливати Пушкінську вулицю», - описував події газетний кореспондент ${ }^{111}$.

Прибуття до Одеси кількох «революційних» загонів із Румунського фрронту забезпечило прихильникам радянської влади чисельну перевагу над захисниками Центральної Ради ${ }^{112}$. Оборону українських вояків ослабила втрата панцерників під час боїв у центрі міста. Водночас робітники-залізничники спрямували проти гайдамаків мотоброневагон «Заамурець», озброєний гарматами й кулеметами ${ }^{113}$. Та головне, вогнева міць української артилерії була недостатньою, щоб протистояти корабельним гарматам.

Уранці 29 січня 1918 р. лінійні кораблі «Ростислав» та «Синоп» відновили обстріл українських позицій. Упродовж першої половини дня червоні остаточно відтіснили гайдамаків до вокзалу, який однак не спромоглися захопити ${ }^{114}$. Але й українські вояки не могли довго протриматися під нищівним гарматним вогнем. «Снаряди влучили не лише у приміщення вокзалу, а й у Пантелеймонівське подвір'я та сусідні з вокзалом будівлі, які сильно постраждали, - свідчив очевидець. - До 9 год. частина вокзалу загорілася» ${ }^{115}$.

Унаслідок переваги червоних в артилерії й живій силі становище українських вояків надвечір 29 січня 1918 р. стало критичним. О 19-й год. того дня командування запропонувало ВРК укласти перемир'я. У відповідь ревком зажадав від захисників Центральної Ради скласти зброю й видати всіх офіцерів ${ }^{116}$. Оскільки ці умови були неприйнятними для української сторони, бойові дії відновилися.

Нейтралітет більшості гайдамаків, відсутність підмоги, чутки про більшовицький переворот у Києві та встановлення радянської влади в містах Херсонщини послаблювали бойовий дух українських бійців. За свідченням очевидця, вояки «поодинці й групами почали залишати свої позиції» ${ }^{117}$. Становище гайдамаків погіршилося ще більше, коли корабельна артилерія

110 Гришко Г. 1917 рік в Одесі... // Розбудова нації. - 1930. - Ч.11/12 (35/36). - С.290.

111 Ив. Г. Из личных впечатлений. - С.2.

112 Революционная рота // Одесский листок. - 1918. - 18 января. - №11. - С.1; ЦДАВО України. - Ф.3156. - Оп.1. - Спр.172. - Арк.186; Дегтярев Л. Октябрь Румынского фронта (по личным воспоминаниям) // Красная летопись. - 1923. - №6. - С.272-273.

113 Державний архів Одеської області. - Ф.П-13. - Оп.3. - Спр.206. - Арк.32.

114 Гражданская война: Сводка событий // Одесский листок. - 1918. - 19 января. - №12. - С.2;

На вокзале // Там же. - 18 января. - №11. - С.2; Кривошеев А. Октябрь на Юге. - С.121.

115 Ив. Г. Из личных впечатлений. - С.2.

116 Условия, предложенные гайдамакам // Одесский листок. - 1918. - 18 января. - №11. - С.1; Братоубийственная война. - С.1.

117 ЦДАГО України. - Ф.59. - Оп.1. - Спр.687. - Арк.35 зв. 
перенесла свій вогонь на українські казарми в південному передмісті ${ }^{118}$. Кілька тисяч нейтральних вояків, не бажаючи стати жертвами обстрілів, зажадали від командування негайно припинити боротьбу. Увечері делегація від «нейтралів» прибула до штабу червоної гвардії домовлятися про умови припинення бойових дій. Делегати погодилися видати офіцерів і пообіцяли примусити своїх товаришів, які вже два дні поспіль билися з більшовиками, скласти зброю ${ }^{119}$.

Готовність більшої частини української залоги прийняти вимоги ВРК остаточно змінила співвідношення сил в Одесі. Ледь стримуючи ворога у центрі міста, захисники Центральної Ради не могли сподіватися здолати ще й новоспечених більшовицьких союзників у своєму тилу. Тож у ніч на 30 січня 1918 р. українське командування вирішило припинити збройну боротьбу. Бійці одержали наказ розсіюватися та пробиватися за межі Одеси.

Відступ захисників Центральної Ради відбувався без значних сутичок. Винятком став запеклий бій біля вокзалу, який жменька гайдамаків до останнього захищала від противника. До світанку 30 січня 1918 р. червона артилерія припинила вогонь за домовленістю з представниками “нейтральних» підрозділів $^{120}$. Останні виконали свою частину угоди, доправивши до штабу червоної гвардії заарештованих офіцерів та учасників збройної боротьби. За свідченням члена ВРК А.Кривошеєва, усього було видано 200 чол. ${ }^{121}$ Аби запобігти відступові гайдамаків, червоні виставили застави на шляху до Акермана. Однак ґенералові Ю.Єлчанинову, полковникові М.Мазуренку, капітанові В.Змієнку та багатьом іншим старшинам і воякам удалося обійти ворожі пости й залишити місто.

За повідомленнями одеської преси, втрати кожної сторони у вуличних боях складали близько 20 вбитих і 60 поранених ${ }^{122}$. Але швидше всього, ці дані далеко не повні. Усіх полеглих гайдамаків та їхніх противників за декілька днів поховали у двох братських могилах на Куликовому полі ${ }^{123}$. А.Кривошеєв стверджував, що червоні розстріляли лише незначну кількість бранців, а решту звільнили після обіцянки не воювати більше проти радвлади ${ }^{124}$. Проте збереглися свідчення про випадки розправи над українськими полоненими. «Усе вище військове начальство, не встигнувши відступити, було нами перебито», згадував один із червоногвардійців ${ }^{125}$. На станції Одеса-Головна розстріляли кількох полонених вояків ${ }^{126}$.

118 Кривошеев А. Октябрь на Юге - С.120; Державний архів Одеської області. - Ф.П-2. Оп.1. - Спр.882. - Арк.11.

119 Братоубийственная война. - С.1; Кривошеев А. Октябрь на Юге. - С.122-123; Ачканов $Г$. 3 спогадів про Лютневу, Жовтневу революції... - С.410.

120 Гражданская война: Сводка событий. - С.2.

${ }^{121}$ Кривошеев А. Октябрь на Юге. - С.123-124.

122 Гончарук Т. Жертви подій 15-17 січня 1918 р. в Одесі на сторінках газет «Одесские новости» та «Одесский листок» // Південний Захід: Одесика: Історико-краезнавчий науковий альманах. - Вип.13. - Одеса, 2013. - С.113. Див. також: Сколько убитых и раненых // Одесские новости. - 1918. - 19 января. - №10617. - С.1.

${ }^{123}$ О похоронах жертв // Одесский листок. - 1918. - 20 января. - №13. - С.3. Див. також: Протоколи одеської Ради робітничих депутатів // Літопис революції. - 1931. - №3. - С.176.

${ }_{124}$ Кривошеев А. Октябрь на Юге. - С.130.

125 Российский государственный военный архив. - Ф.28361. - Оп.1. - Д.732. - Л.42-43.

126 Державний архів Одеської області. - Ф.П-2. - Оп.1. - Спр.945. - Арк.2 зв. 
30 січня 1918 р. ВРК повідомив мешканців Одеси про закінчення збройної боротьби та встановлення в місті радянської влади. Відповідно до умов припинення бойових дій ревком отримав право розпоряджатися всіма військовими силами в місті. В українських частинах запроваджувалося виборне начало. «Товариші гайдамаки» навіть отримали право безперешкодного пересування містом за наявності мандатів від своїх виборних організацій. Підпис під мирною угодою поставили представники 1-го Гайдамацького кінного полку, 1-го, 2-го, 3-го Гайдамацьких пластунських полків ${ }^{127}$.

Небезпека румунського вторгнення, а згодом і загроза австро-німецької інтервенції не надто непокоїли «нейтральних» українських вояків, які клопоталися лише про якомога швидше звільнення з лав армії. Натомість одеська організація «українських соціал-демократів-більшовиків» намагалася сдрормувати з українських вояків загони для боротьби за радянську владу. 14 лютого 1918 р. голова ціеї політичної групи М.Матяш прохав Румчерод затвердити О.Курганова на посаді комісара зі справ українських частин ${ }^{128}$. Оскільки у штабі В.Антонова-Овсієнка не заперечували проти подібної ініціативи, уже 26 лютого М.Матяш заявив на засіданні Румчероду про необхідність «формування українського червоного війська» ${ }^{129}$. Але Румчерод зважився дати дозвіл на формування загонів українського червоного козацтва аж 11 березня ${ }^{130}$. Таке тривале зволікання представників радянської влади, очевидно, можна пояснити сумнівами в політичній благонадійності українських вояків.

Та в будь-якому разі спроба створити в Одесі українські радянські війська не принесла результату, адже переважна більшість гайдамаків воліли демобілізуватися й вирушити додому. Командувач радянських військ Одеського району М.Муравйов нарікав, що «одеська рада не дала жодного батальйону» ${ }^{131}$. Коли австро-німецькі війська у середині березня 1918 р. ввійшли до Одеси, у місті вже не існувало організованої української військової сили, здатної вплинути на перебіг бойових дій.

Хоча навесні 1918 р. полковник М.Мазуренко і сотник В.Змієнко успішно продовжили військову службу у збройних силах УНР, представники української влади не робили спроб відродити в Одесі гайдамацьке військове формування. Після вигнання більшовиків одеський гарнізон склали частини й підрозділи, які прибули з Румунського фрронту: 4-та стрілецька, 15-та піхотна дивізіі, 4-й панцерний кулеметний дивізіон, технічні підрозділи ${ }^{132}$. Попри навіть те, що 4-та стрілецька дивізія частково українізувалася, це були армійські з’еннання російської армії. Національним військовим підрозділом міг уважатися лише гайдамацький курінь «Вільна Україна», сформований на фрронті 3

127 Братоубийственная война. - С.1; Мирный договор между украинскими и советскими войсками // Одесский листок. - 1918. - 18 января. - №11. - С.1.

128 ЦДАВО України. - Ф.3156. - Оп.1. - Спр.172. - Арк.308.

129 ГАРФ. - Ф.1029. - Оп.1. - Д.23. - Л.35; ЦДАВО України. - Ф.3156. - Оп.1. - Спр.16. Арк. 25 зв.

130 ЦДАВО України. - Ф.3156. - Оп.1. - Спр.15. - Арк.30.

131 Антонов-Овсеенко В. Записки о гражданской войне. - Т.2. - Москва; Ленинград, 1928. C.12-13.

132 ЦДАВО України. - Ф.1076. - Оп.1. - Спр.2 а. - Арк.33; Спр.14. - Арк.99. 
українського ударного батальйону 71-ї дивізії ${ }^{133}$. У квітні 1918 р. розпочалося переформування цих військ на частини 3-го Херсонського корпусу Армії УНР, але гетьманський переворот П.Скоропадського започаткував нову сторінку в історії української держави та її збройних сил.

Таким чином, у 1917-1918 рр. Одесі судилося стати одним із місць найбільш інтенсивного формування українського війська. Започаткована на хвилі національного відродження, організація гайдамацьких частин була нерозривно пов'язана з притаманною причорноморському регіону козацькою традицією. Упродовж другої половини 1917 - на початку 1918 рр. новітні гайдамаки виступали головною військовою силою Центральної Ради не лише в Одесі, але й загалом на півдні України. Високий рівень боєздатності цій частині в перші місяці їі існування забезпечив добровільний принцип комплектування та сувора система відбору новобранців. Спроба розгорнути на базі гайдамацької бригади повноцінне військове з'єднання призвела до зниження її якості як бойової сили й засвідчила невиправданість відходу від добровільних засад формування в умовах глибокої суспільно-політичної кризи. Якщо збройна боротьба захисників української справи проти більшовицького перевороту в Одесі збагатила героїчними сторінками історію війни за незалежність 1917-1920 рр., то «нейтралітет» їхніх товаришів по зброї став зайвим доказом неможливості збудувати міщну регулярну армію під час соціальних потрясінь звичними для дореволюційної епохи методами.

133 Сірко-Біляга Д. Спомини з 1917-1921 pp. // Biblioteka Narodowa w Warszawie. - Archiwum im. Tarasa Szewczenki. - M/f. 87501. - S.2-2 obr.

On the basing of many historical sources including first-introduced to researchers author discloses history of Ukrainian military formations created in Odesa during 1917 - beginning of 1918. The article reconstitutes in details the main phases of organization and military activity of Haidamaks which were the principle armed forces of the Ukrainian People's Republic government in the Southern Ukraine. Author scrutinizes issues connected with influence exerted by Ukrainian figures and Russian high-ranked officers for creation of national military units in Odesa. Author defines the basic principles of Ukrainian military formation's organization and concludes their compliance with the requirements of time.

Keywords: Central Rada (Central Council), revolution, Ukrainian People's Republic, Army of UPR, Ukrainian military movement.

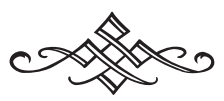

